\title{
MERANCANG ASESMEN KINERJA PADA PEMBELAJARAN PRAKARYA TEKNIK LAS BERORIENTASI PRODUK DI SMK
}

\author{
Daniel Santoso ${ }^{1}$, Wahid Munawar ${ }^{2}$, Sriyono $^{3}$ \\ Departemen Pendidikan Teknik Mesin \\ Universitas Pendidikan Indonesia \\ Jl. Dr. Setiabudhi No. 207 Bandung 40154 \\ hansipxtm@gmail.com
}

\begin{abstract}
ABSTRAK
Penelitian ini bertujuan untuk merancang dan menganalisis penilaian kinerja pada keterampilan las berorientasikan produk. Metode penelitian ini menggunakan metode deskriptif dengan mengambil subjek empat orang peserta didik dari dua SMK yang berbeda yaitu di SMK Negeri 1 Cikaum pada peserta didik kelas XI Teknik Sepeda Motor (TSM) dan peserta didik di SMK Negeri 12 Bandung kelas XI Pemesinan. Metode pengumpulan data diperoleh dari hasil perancangan instrumen asesmen kinerja membuat produk pengelasan dan dilaksanakan uji kelayakan oleh judgement expert dengan Content Validity Rasio (CVR) dan Content Validity Index (CVI). Hasil validasi instrumen menunjukan jumlah indikator kerja yang valid yaitu 0,98 dan hasil penelitian dari penerapan instrumen menunjukan bahwa peserta didik kelas XI TSM mendapatkan nilai rata-rata 75 dan peserta didik kelas XI Pemesinan mendapatkan nilai rata-rata 80 serta untuk rata-rata pencapaian waktu yang diperoleh dari semua subjek didapat 157menit.
\end{abstract}

Kata kunci: asesmen, kinerja, las, prakarya, orientasi

\section{PENDAHULUAN}

Usaha mengembangkan manusia berkualitas yang siap menghadapi berbagai tantangan hidup dimulai sedini mungkin melalui pendidikan. Kegiatan pendidikan yang diberikan, antara lain melalui sejumlah mata pelajaran yang dimaksudkan untuk memberikan pengalaman belajar yang bermakna dan bervariasi bagi peserta didik, salah satu upaya pendidikan yang diharapkan mampu mengembangkan potensi dan keterampilan peserta didik di Sekolah Menengah Kejuruan (SMK) adalah pembelajaran keterampilan las dengan berorientasi kepada pembuatan hasil karya suatu produk. Program produktif adalah kelompok mata diklat yang berfungsi membekali peserta didik agar memiliki kompetensi kerja sesuai dengan Standar Kompetensi Kerja Nasional Indonesia (SKKNI), dan penilaian kinerja peserta didik yang sesuai dengan Badan Nasional Standar Penddikan (BNSP). Kenyataan dilapangan berdasarkan observasi dan wawancara dilokasi penelitian, guru jarang menerapkan asesmen kinerja yang baik karena penilaian kinerja hanya dilakukan secara subjektif dan tidak objektif berdasarkan acuan suatu asesmen kinerja, kondisi ini tidak sesuai dengan tujuan pendidikan, karena peserta didik perlu dievaluasi dengan baik

\footnotetext{
${ }^{1}$ Mahasiswa Departemen Pendidikan Teknik Mesin FPTK UPI

${ }^{2}$ Dosen Departemen Pendidikan Teknik Mesin FPTK UPI

${ }^{3}$ Dosen Departemen Pendidikan Teknik Mesin FPTK UPI
} 
sesuai dengan keahliannya sebagai pelajar yang harus berkompetensi di dunia kejuruan dan guru yang profesional harus memiliki standar penilaian yang baik pula, salah satunya diterapkan pada perancangan asesmen keterampilan membuat prakarya produk pengelasan.

Pelaksanaan Kegiatan Belajar Mengajar (KBM) di SMK khususnya SMK Negeri 1 Cikaum dan SMK Negeri 12 Bandung dalam pembelajaran keterampilan pengelasan dengan kegiatan praktikum, menjadi pilihan utama untuk menunjang salah satu kompetensi yang wajib dimiliki oleh peserta didik. Dalam prosesnya peserta didik lebih tertarik dan termotivasi pada pembelajaran praktikum dibandingkan dengan proses belajar mengajar yang dilaksanakan di kelas. Kegiatan praktikum peserta didik dapat melakukan penerapan materi dan pembelajaran yang didapatnya di dalam kelas. Seiring dengan lebih banyaknya kegiatan praktikum, kegiatan penilaian bagi peserta didik harus dilakukan, yaitu dengan penilaian kinerja atau performance assessment.

Tujuan penelitian ini, yaitu: merancang asesmen kinerja pada pembelajaran pengelasan berorientasikan produk di SMK, dan menerapkan asesmen kinerja pada pembelajaran pengelasan berorientasikan produk di SMK. Penilaian kinerja digunakan untuk menguji kemampuan peserta didik dalam mendemonstrasikan pengetahuan dan keterampilannya pada berbagai situasi nyata dan konteks tertentu. Penilaian ini bukan hanya dimaksudkan untuk menguji ingatan faktual peserta didik melainkan untuk menilai penerapan pengetahuan faktual dan konsep-konsep ilmiah peserta didik. Performance based assessment is a test of the ability to apply knowledge, skills and understanding, ussualy in a real life setting (Isaacs, 2013). Pentingnya penilaian pendidikan kejuruan dalam hal praktik kinerja untuk menunjang kompetensi keahlian peserta didik yang dalam penelitian ini adalah kompetensi pengelasan.

Penilaian kinerja merupakan salah satu bentuk penilaian yang mencoba melihat kompetensi peserta didik tidak hanya dari segi kognitif saja, akan tetapi psikomotoriknya. Prinsip penilaian pada dasarnya adalah proses untuk memperoleh informasi dan fakta-fakta dari hasil keterangan yang dinilai untuk menjadi keputusan (Arikunto, 2009). Belajar menduduki peran yang sangat penting baik dalam konteks kehidupan umat manusia maupun dalam konteks kehidupan semua mahluk hidup lainnya di bumi ini, agar kehidupan mereka dapat terus berlangsung, Pembelajaran sebagai a relatively permanen change in behavioral potentiality that occurs as a result of reinforced practice (Hergenhahn dan Olson, 1993). Teori belajar merupakan upaya untuk mendeskripsikan bagaimana manusia belajar, sehingga membantu kita semua memahami prosesnya. Ada tiga perspektif utama dalam teori belajar, yaitu behaviorisme, 
kognitivisme, dan kontruktivisme yang pada dasarnya teori pertama dilengkapi oleh teori kedua dan seterusnya, sehingga ada varian, dan gagasan utama dari setiap perkembangan teori. Skill is a concept that is context-based and task specific", skill theory concepts obsiously demand dynamic analysis of development and learning, and dynamic systems theory provides not only an emphasis on analysis of variation but also powerful analytic tools a focus on complex growth patterns such as analysis as that for optimal level in (Fischer dan Yan, 2003).

Tujuan mata pelajaran keterampilan vokasional yang terdapat dalam kurikulum 2006 tentang standar kompetensi dan kompetensi dasar adalah menumbuh kembangkan daya apresiasi dan etos kerja dalam bidang teknologi sesuai kemampuan peserta didik, mengembangkan kemampuan imajinatif, intelektual, kreatifitas yang dapat memberikan bekal kemampuan (sikap, pengetahuan dan keterampilan) yang dapat bermanfaat bagi peserta didik dalam kehidupan sebagai anggota masyarakat maupun sebagai warga negara yang kreatif dan produktif, dan membentuk peserta didik mempunyai kepribadian yang percaya diri dan dapat hidup mandiri.

Pengelasan merupakan penyambungan dua bahan atau lebih yang didasarkan pada prinsip-prinsip proses difusi, sehingga terjadi penyatuan bagian bahan yang disambung. Kelebihan sambungan las adalah konstruksi ringan, dapat menahan kekuatan yang tinggi, mudah pelaksanaannya, serta cukup ekonomis. Namun kelemahan yang paling utama adalah terjadinya perubahan struktur mikro bahan yang dilas, sehingga terjadi perubahan sifat fisik maupun mekanis dari bahan yang dilas.

\section{METODE PENELITIAN}

Metode yang akan digunakan dalam penelitian ini adalah metode deskriptif.

Penelitian deskriptif jenis analisis kegiatan ini bertujuan untuk menganalisis kegiatan yang dilakukan dalam membuat suatu rancangan asesmen kinerja yang digunakan untuk menilai hasil dari kegiatan keterampilan membuat produk pengelasan di SMK Otomotif dan SMK Pemesinan lalu mendeskripsikan hasil analisis kegiatan yang dilakukan tersebut. Subjek dalam penelitian ini diambil sebanyak 4 peserta didik yang diambil 2 dari tiap SMK yaitu 2 peserta didik kelas XI TSM dan 2 peserta didik XI Pemesinan. Analis hasil pengujian validasi instrumen penelitian menurut Lawse (Dalam Wijayati, H.P. 2013, hlm. 324), dilakukan menggunakan Content Validity Rasio (CVR) dan Content Validity Index (CVI). 


\section{HASIL PENELITIAN}

Perhitungan nilai CVR dapat dicontohkan pada analisa untuk tes kinerja pengerjaan membuat bangku. Tahap persiapan kerja yaitu:

$n_{e}=$ validator yang setuju $=3$

$N=$ jumlah total validator $=3$

Nilai CVR =

$C V R=\frac{n_{e}-N / 2}{N / 2}=\frac{3-3 / 2}{3 / 2}=\frac{3-1,5}{1,5}=1($ sangat valid $)$

Analisis hasil pengujian validitas tes kinerja pengerjaan teknik las membuat bangku menggunakan CVI, sebagai berkut:

Jumlah item $=60$

Jumlah total CVR $=58,5$

Nilai CVI $=\frac{\text { Jumlah CVR }}{\text { Jumlah item }}=\frac{58,8}{60}=0,98($ sangat valid $)$

Pengujian validitas oleh para ahli terhadap instrumen-instrumen penelitian di atas dapat dilihat pada tabel-tabelyang terdapat pada lampiran. Hasil pengujian oleh ahli tersebut dianalisis menggunakan Content Validity Rasio (CVR) dan Content Validity Index (CVI). Hasil pengujian CVI pada pengerjaan bangku diperoleh nilai 0,98 artinya nilai tersebut sangat valid atau dapat dipercaya. Berdasarkan nilai CVI yang didapat, tes kinerja pengerjaan teknik las membuat bangku ini secara keseluruhan dinyatakan sangat valid dan dapat digunakan karena memenuhi nilai CVI > 0,67 (Wijayati, 2013). Item-item dengan hasil tidak valid dapat tetap dipakai namun dengan perbaikan atau tidak dipakai sama sekali. Nilai hasil langkah kerja pada perfoemance test diperoleh nilai AY=75, AS=75, $\mathrm{TG}=80$, dan $\mathrm{FP}=80$. Ketercapaian rata-rata waktu pada pengelasan membuat produk bangku yang dicapai peserta didik didapat 157 menit.

\section{KESIMPULAN}

Perancangan asesmen kinerja ini dilakukan dengan memvalidasi instrumen penilaian kinerja oleh judgement expert dan didapat hasil dari Content Validity Index (CVI) sebesar 0,98 atau lebih dari 0,67. Hasil dari penerapan pada subjek penelitian yaitu empat peserta didik di dua SMK yang berbeda diperoleh nilai rata-rata 75. Peserta didik jurusan TSM memperoleh nilai rata-rata 80 dan jurusan Pemesinan rata-rata pencapaian waktu yang diperoleh 157menit. 


\section{DAFTAR PUSTAKA}

Arikunto, S. (2009). Dasar-dasar Evaluasi Pendidikan. Jakarta: PT. Bumi Aksara.

Fischer, K. dan Yan, Z. (2003). The Development of Dynamic Skill Theory. Harvard University Graduate School of Education.

Hergenhahn, B.R. and Olson, M. H. (1993). An Introduction to Theories of Learning $\left(4^{\text {th }}\right.$ Ed). New Jersey: Prentice Hall.

Isaacs,T. dkk. (2013). Key Concepts In Educational Assessment. London: Sage, British Library.

Wijayanti, H.P. (2013). Model Evaluasi Pembelajarn Berbasis Kaizen Di Sekolah Menengah Atas. Malang: Universitas Negeri Malang. 